\title{
Claude Kastler - představitel slavistiky a propagátor českého jazyka ve Francii
}

\author{
Milena Nosková (České Budějovice)
}

\begin{abstract}
Abstrakt
Přispěvek se zabývá odkazem významného zástupce francouzské slavistiky 20. stol. Clauda Kastlera (19362011), který jako predstavitel slovanské srovnávací jazykovědy přispěl k vědeckému a pedagogickému rozvoji bohemistických studií na Stendhalově univerzitě v Grenoblu (dnes Université Grenoble Alpes). Zájem o češtinu vyvolaly zejména události pražského jara 1968, kdy Kastler byl povolán na univerzitu. Vedle polské a ruské mluvnice svou pozornost zaměřil na komunikační a lingvodidaktický výzkum češtiny jako cizího jazyka, který se odrazil v jeho syntetizující, „praktické a promyšlené“ mluvnici La langue tchèque (1995). Jako rusista vynikl monografií Un bolchévique fou de littérature (1995) o ruském prozaiku a literárním kritiku Alexandru Voronském. Svým dílem a pedagogickým působením navázal na silnou tradici francouzské kulturněhistorické a filologické slavistiky (E. Denis, A. Mazon, A. Meillet, L. Leger ad.).
\end{abstract}

\section{Klíčová slova}

slavistika; Francie; bohemistika; Claude Kastler; lingvistika; česko-francouzské vztahy

\section{Abstract \\ Claude Kastler - a Leading Slavonic Scholar and Czech Language Promoter in France}

The paper explores the legacy of Claude Kastler (1936-2011), a major figure in the 20th-century Slavonic studies in France whose research and teaching activities as the leading representative of the Slavonic comparative literature made him instrumental in the promotion of Czech Studies at the University of Grenoble (today the Université Grenoble Alpes). His interest in the Czech language was in particular due to the Prague Spring events of 1968, when he joined the University. Besides Polish and Russian grammar, Kastler's researches were focused on the communicative and linguodidactic study of Czech as a foreign language, which is reflected in his synthesising, "practical and well-designed" grammar of La langue tchèque (1995). Thus in both his works and teaching practice, Kastler followed in the distinguished tradition of cultural, historical, and philological studies of Slavonic nations in France (E. Denis, A. Mazon, A. Meillet, L. Leger, etc.).

\section{Key words}

Slavonic Studies; France; Czech Studies; Claude Kastle; linguistics; Czech-French relations 
Česká republika a Francie jsou geograficky relativně vzdálené země, ale z pohledu kultury, literatury, studia jazyků - především slovanských - tato vzdálenost mnoho neznamená. V meziválečné Československé republice se stal velmi důležitým centrem slavistické práce Slovanský ústav v Praze, jehož úkolem bylo studium slovanských národů, studium jejich kultury. ${ }^{1}$ Záměr zřídit tento ústav byl ovlivněn pařížským Institut d'Études slaves (Institut slovanských studií) a s posláním tohoto ústavu se československá veřejnost seznámila prostřednictvím překladu Denisova spisku Ústav pro studium Slovanstva. Pař́ž středisko slavistiky v cizině. ${ }^{2}$ Institut slovanských studií byl ustaven 9. 3. 1920 a do vedení zvolen Ernest Denis. Antoine Meillet, významný francouzský komparatista, profesor Collège de France, byl zvolen vědeckým ředitelem; generálním tajemníkem se stal Ludvík Eisenmann, profesor Sorbonny. Ústav měl mít čistě vědecký ráz, jeho úkolem bylo sdružovat všechny, kteří se zabývají slovanskými otázkami .

Zájem Francie o slovanské země má delší tradici, a to již od 18. století, Francie se zajímala především o Polsko, důvodem bylo geopolitické hledisko. A již v roce 1610 Jindřich IV. založil konzulát v Gdaňsku. Pokud jde o Rusko, je nutné připomenout, že v období regentské vlády Filipa Orleánského za nezletilého Ludvíka XV. gramatik Gabriel Girard byl velmi nakloněn ruštině a staroslověnštině. V roce 1724, Jean Sohier, atašé Královské knihovny, redigoval své dílo pod názvem Grammaire $\mathcal{E}$ Méthode russes et française, první popis ruštiny z pera Francouze. V 19. století, přesněji v roce 1840 , byla založena první katedra slovanského jazyka v Collège de France na počest polského spisovatele Adama Mickiewicze. Roku 1868 průkopník francouzské slavistiky Louis Leger obhájil své práce na téma Chronique de Nestor (první ruská kronika) a Cyrille et Méthode. Na Sorbonně vyučoval literární historii jižních Slovanů, historii Srbska, srbskou a ruskou gramatiku a také českou historii. Jeho jméno je dnes známo pouze odborníkům, nikoli náhodou byla na jeho počest pojmenována jedna z centrálních ulic v Praze. V poslední čtvrtině 19. století, konkrétně v roce 1874 , byl ve Škole východních jazyků (École des langues orientales $)^{5}$ zahájen první kurs ruštiny, jehož vedením byl pověřen výše zmiňovaný Louis Leger. O čtyři roky později zde byla otevřena katedra slavistiky, kde se nejprve vyučovala srbština a chorvatština a poté se vyučující věnovali pouze ruštině. Výuka ruštiny se rozvíjela především za pomoci Paula Boyera, přítele významného lingvisty Antoina Meilleta. Meillet byl vynikající pedagog a svým dílem Manuel pour l'étude de la langue russe založil nauku o výuce ruštiny adaptovanou pro Francouze. Po dobu tří století byla slavistika exkluzivně německá. Slovanské jazyky se vyučovaly na německých univerzitách od 17. sto-

1 Srov. ZELENKA, Miloš: Le rôle de la slavistique française dans l'essor institutionnel et l'orientation intellectuelle de la slavistique tchèque après 1918 (André Mazon et Matija Murko dans les années 1920). Revue des études slaves (Paris) 91, 2020, č. 1, s. 119-137.

2 KUDĚLKA, Milan - ŠIMEČEK, Zdeněk - ŠŤASTNÝ, Vladislav - VEČERKA, Radoslav: Československá slavistika v letech 1918-1939. Praha: Academia, 1977, s. 82.

3 DENIS, Arnošt: Ústav pro studium Slovanstva. Pař́ž středisko slavistiky v cizině. Přel. Karel Havránek. Praha: nakladatel Jan Laichter, 1921, s. 5-6.

4 Tamtéž, s. 21.

5 École des langues orientales (INALCO) - instituce založena roku 1669, výuka a výzkum jazyků a kultur východní Evropy. 
letí. Nelze opomenout, že německy jsou vydávána velká díla slovanské lingvistiky. Jedná se o slovanské vědce, jakými byli Josef Dobrovský, který publikoval také latinsky, Slovinec Jernej Kopitar, Pavel Josef Šafařík, Slovinec Franc Miklošič či Chorvat Vatroslav Jagić.

V 19. století byly zakládány další katedry ruštiny, např́ḱlad v Lille v roce 1892, nebot' v tomto severofrancouzském městě probíhala čilá obchodní výměna mezi Francií a Ruskem především v oblasti textilního průmyslu. O deset let později, roku 1902, byla založena druhá katedra ruštiny na pařížské Sorbonně. Za průkopníky této epochy jsou označováni Jules Patouillet, Émile Haumant, André Lirondelle, Jules Legras, Raoul Labry, André Vaillant a mladý vědec André Mazon, bratr znalce starořecké kultury Paula Mazona. Po skončení první světové války, v roce 1919, dva slovanské státy reagovaly na výzvu francouzské vlády, a to ve smyslu založení Institutu slovanských studií (Institut d'études slaves) ${ }^{6}$. Profesor historie na Sorbonně, Ernest Denis, stoupenec slovanských národů a zejména českého národa, postoupil Sorbonně svoji soukromou budovu v pařížské ulici Michelet, budovu, v níž se nacházel pozdější Institut slovanských studií. Ten byl slavnostně inaugurován v říjnu 1923 za účasti významných osobností (mj. T. G. Masaryk, E. Denis, A. Meillet). Posláním této instituce měl být rozvoj intelektuálních vztahů, prohloubení znalostí o slovanském světě, studium slovanských jazyků a literatur. V roce 1921 začíná vycházet slavistický časopis Revue des études slaves a je také založena knihovna, která funguje od roku 1924.

Nový pohled na slovanské země ovlivnil oborovou strukturu ostatních univerzit, které zakládají nové katedry. V roce 1919 je otevřena katedra slovanských jazyků ve Štrasburku a svěřena André Mazonovi (1881-1967), který jako francouzský intelektuál inspirovaný principy slovanské humanity na této univerzitě v rámci slavistiky otevřel samostatné oddělení českého jazyka a literatury. Mazon v roce 1919 několik měsíců prožil na doporučení svého učitele Louise Eisenmanna v Praze jako tlumočník generála Maurice Pellé, který stál v čele oficiální vojenské mise podílející se na vytvoření nového československého generálního štábu. Mazon již v roce 1921 napsal analyticky koncipovanou Grammaire de la langue tchèque. Druhé vydání vyšlo v roce 1931 a třetí vydání je z roku 1952 a obsahuje pojednání o vývoji spisovného jazyka, výklady o pravopise, výslovnosti a skladbě.7 Po Štrasburku následovaly univerzity v Dijonu (1920) a Lyonu (1921). Současně za pomoci francouzské vlády Ernest Denis založil Francouzský institut v Praze (Institut français de Prague) roku 1919, který měl sekci literární, právní a vědeckou. Mnichovská dohoda ze září 1938 znamenala tragický konec velkého projektu Ernesta Denise, Antoina Meilleta, Tomáše G. Masaryka a dalších intelektuálo̊, projektu, který úzce souvisel se založením Institutu slovanských jazyků. Po roce 1945 se francouzská slavistika orientovala spíše na Rusko. Osvobození bylo momentem velkého nadšení pro ruský jazyk, oficiální jazyk SSSR. „Agrégation de russe“, což znamená způsobilost vyučovat ruštinu na vyšších středních školách, byla oficiálně vytvořena před válkou, ovšem nedošlo k jejímu otevření, fungovat začala od roku 1947. Během následujících dvaceti let na francouzských univerzitách (např. Bordeaux, Rennes, Nancy, Poitiers, Grenoble, Toulouse a další) začaly vznikat

6 Institut d'études slaves - založen v roce 1919 Ernstem Denisem, tato instituce sloužila k přijetí a podpoře studentů ruské diaspory.

7 HAVRÁNEK, Bohumil: André Mazon, Grammaire de la langue tchèque. Naše řeč 7, 1923, č. 10, s. 298. 
katedry slovanských jazyků, které se staly centrem výuky ruštiny a ostatních slovanských jazyků.

Pedagogická bohemistika zaměřená nejen na výuku češtiny na všech stupních škol, ale i na výuku češtiny jako cizího jazyka, jak vyplývá z výše jmenovaného, a jazykovědná bohemistika se pěstují také v zahraničí, kde jsou součástí slavistických ústavů${ }^{8}$. V současnosti je možné český jazyk a literaturu ve Francii studovat na několika lektorátech. V akademickém roce 2019/2020 se jedná o lektoráty v Aix-en-Provence (Aix - Marseille Université), v Dijonu (Université de Bourgogne a Lycée Carnot), v Nîmes (Lycée A. Daudet), v Paříži na Université Paris IV-Sorbonne, kde je bohemistika součástí katedry slavistiky - založena byla v roce 1982 profesorkou Hanou Voisine-Jechovou. Český jazyk, literaturu a historii lze rovněž studovat v Národním institutu východních jazyků a civilizací (INAL$\mathrm{CO}$ - Institut national des langues et civilisations orientales ${ }^{9}$ ). K výčtu francouzských institucí vyučujících oborově češtinu (anebo v rámci slavistiky) je třeba přiřadit i Stendhalovu univerzitu v Grenoblu (dnešní Université Grenoble Alpes). Hlavní zásluhu na její vědecké a pedagogické formování měl především profesor Claude Kastler (1936-2011), který se narodil v Caudéran blízko Bordeaux v rodině nositele Nobelovy ceny za fyziku Alfréda Kastlera, profesora na Ecole normale supérieure. Matka Élise Cosset byla středoškolskou profesorkou historie a geografie. Kastlerův starší bratr Daniel se stal profesorem matematiky na univerzitě v Marseille a sestra Mireille pracovala jako oční lékařka v Paříži. Svá středoškolská (lyceum Montaigne, poté Louis-le-Grand) a vysokoškolská studia Kastler absolvoval v Paříži. Na Sorbonně studoval němčinu, ruštinu a češtinu. V roce 1959 obdržel stipendium ministerstva zahraničních věcí a tím mohl studovat na Lomonosovově univerzitě v Moskvě. Zde prožil jeden akademický rok a díky tomuto pobytu si prohloubil znalosti ruské poezie a literatury 20. století a posílil sympatii nejen k ruské kultuře, ale i k malým středoevropským zemím, především k Československu. Zajímal se o literaturu, historii a zeměpis, filozofii a teologii, botaniku a další oblasti lidské činnosti. Velkou vášní Clauda Kastlera byly jazyky, které ho lákaly již od dětství. Studoval klasické jazyky, latinu a zvláště starou řečtinu, velmi dobře znal příběhy z řecké mytologie. Studium jazyků mu ulehčilo i hudební nadání, nebot hrál na violoncello. Claude Kastler slovanské jazyky nepovažoval jen za objekt svých lingvistických výzkumů, ale především za prostředek komunikace $\mathrm{s}$ představiteli jiných kultur. Z těchto důvodů v gramatikách tří slovanských jazyků, jejichž je autorem, se komunikativní aspekt objevuje na prvním místě ${ }^{10}$. Gramatické jevy se snaží představit jednoduše, nebot jeho pedagogický přístup byl v duchu Komenského „radostného vědění“. Jeho snahou bylo dát gramatickým pra-

8 KARLÍK, Petr a kol.: Nový encyklopedický slovnik češtiny A-M. Praha: Nakladatelství Lidové noviny, 2016, S. 183.

9 INALCO (Institut national des langues et civilisations orientales) - instituce založena roku 1669, výuka a výzkum jazyků a kultur východní Evropy.

10 Fonds slaves, BDL, 2018 [online]; ruská knihovna v rámci Bibliothèque Diderot v Lyonu obsahuje více než 100000 dokumentů (nejstarší pocházejí z 16. století) z oblasti dějin ruského a obecně slovanského světa. 
vidlům explicitní formu, z lexikálního hlediska dával přednost frekventovaným výrazům dle frekvenčního slovníku ${ }^{11}$.

Na Stendhalově univerzitě (Université Stendhal), dnešní Université Grenoble Alpes, začínal jako asistent na katedře ruštiny a slovanských jazyků a svoji univerzitní kariéru zakončil coby univerzitní profesor (roku 1997 byl jmenován řádným profesorem) a ředitel Centra současných slovanských studií (Centre d'études slaves contemporaines). Roku 1963 jej pozval do Grenoblu profesor Claude Robert, který na univerzitě právě založil katedru ruštiny. K definitivnímu jmenování Clauda Kastlera v Grenoblu došlo v roce 1968. Pražské jaro podnítilo jeho entusiasmus provázený „bezmocným vztekem“, jak sám autor formuloval v úvodu svého díla ${ }^{12}$ během invaze sovětských vojsk v srpnu téhož roku. V zárí pro studenty zorganizoval intenzivní stáž češtiny. Dále předmětem jeho vědeckého zájmu v oblasti lingvistické bylo srovnávání slovanských jazyků. Kromě ruštiny a češtiny ovládal také polštinu, ovšem ve výuce se nezaměřoval pouze na jazyk, samozřejmou součástí se stala také literatura, historie, kultura.

V pozděǰší vzpomínce Kastler přiznal svou fascinaci českou kulturou - četl Jaroslava Seiferta, Jana Otčenáška, Milana Kunderu, Bohumila Hrabala ad. Jeho rodina žila údajně Masarykovým kultem, který podpořila do jisté míry i „česká“ výchova. ${ }^{13}$ Pracovně vytížená matka jako středoškolská profesorka historie měla mnoho povinností, a proto byly do rodiny povolány mladé české dívky, které přijely jako sloužící „na zkušenou“ z moravského Slavkova. Jednou z nich byla i Květa Žežulová, která malému Claudovi zpívala moravské lidové písně. Nikoli náhodou jako výraz vděčnosti za své citové formování se její jméno objevilo v dedikaci české gramatiky v roce 1995. Jak jsme již uvedli, psaním své české mluvnice, jejiž první verze vznikala v roce 1968 a kterou příznačně charakterizoval jako „anti-tankovou“, symbolicky chápal jako podporu kulturní vyspělosti české společnosti. Podle vlastních slov v této mluvnici „se snažil odpovědět na ty nejchoulostivějš́ otázky české gramatiky, takové, jako je třeba slovesný vid. Snažil jsem se prèdstavit ty jevy jednoduše a vtipně, protože můj pedagogický prístup byl vždy v duchu Komenského 'radostného věděni".". ${ }^{14}$

Na rozdíl od většiny zahraničních bohemistů Kastler rozlišuje spisovnou, hovorovou a obecnou češtinu a jejich místo ve výuce češtiny pro cizince a poté jejich využití v konkrétní situaci. V rámci aplikace gramatických jevů volil př́klady z české beletrie, vycházel např. z díla Milana Kundery, Karla Čapka, Bohumila Hrabala, Václava Havla, Josefa Škvoreckého a dalších. V úvodní kapitole rovněž nechybí zmínka o slovenštině „langue soeur; une petite soeur devenue grande (et qui a quitté la maison)“, o vybraných jevech její abecedy. ${ }^{15}$ Po kompoziční stránce gramatika zahrnuje devět kapitol zabývajících

11 KASTLER, Claude: La langue tchèque. Nouvelle grammaire tchèque pratique et raisonnée. Paris: Ophrys, 1995 , s. 6.

12 Tamtéž.

13 Ahoj, bohemisto, ahoj! Rozhovor s prof. Claudem Kastlerem. Rozhovor vedly L. Froulíková a T. Ibehejová. Krajiny češtiny. Časopis učitelů u krajanských komunit a lektorů českého jazyka a literatury na zahraničních vzdělávacích institucích, 2011, č. 3, s. 53.

14 Tamtéž.

15 KASTLER, Claude: La langue tchèque. Nouvelle grammaire tchèque pratique et raisonnée. Paris: Ophrys, 1995, s. 6-16. 
se fonologií, morfonologii (ve smyslu obecné morfologie) a přísudkovými tvary. V následujících kapitolách se autor věnoval problematice slovním druhů, a to především gramatickým kategoriím deklinačním a skloňování adjektiv, dále podstatným jménům, zájmenům, číslovkám, tvarům oslovovacím, rozkazovacím a emocionálním. Závěrečná kapitola obsahuje základy lexikologie a slovotvorby. Obsahem všech pasáží jsou základní informace dané problematiky včetně mnoha příkladů z běžných komunikativních situací. ${ }^{16}$

Claude Kastler byl činný nejenom v rámci univerzitního života. V letech 1980 až 2003, kdy odešel do důchodu, byl členem 13. sekce CNU (Conseil national des universités). Po dobu dvaceti let připravoval studenty ze Stendhalovy univerzity v Grenoblu na zkoušky z ruštiny $\left(\right.$ CAPES $\left.^{17}\right)$. V roce 1992 obdržel medaili Comenius od českého ministerstva školství a od organizace UNESCO u př́ležitosti 400. výročí narození J. A. Komenského. Profesor Kastler byl oceněn touto medailí za pedagogické a vědecké aktivity v oblasti českého jazyka, literatury a historie. Zařadil se tak k prvním zahraničním bohemistům, kteří toto ocenění obdrželi ${ }^{18}$. V letech 1995-2003 řídil SLAVALP (Centre de recherche en études slaves ${ }^{19}$ ). Během svého univerzitního působení získal u studentů právem pověst empaticky zapáleného vědce s encyklopedickými znalostmi. Vytvořil velkou knihovnu obsahující díla v několika jazycích, díla vztahující se k několika oblastem, jako byla literatura, umění, lingvistika, filozofie. Kromě sběratelské vášně nelze opomenout jeho velký zájem o klasickou hudbu a fotografovánî ${ }^{20}$. Claude Kastler byl jedním z nemnohých slavistů, který vyučoval po dobu několika desetiletí tři slovanské jazyky: ruštinu, polštinu a češtinu. Jeho hlavní díla jsou téměř všechna věnována gramatice slovanských jazyků, a to gramatice české, polské a ruské: Český jazyk. Česká mluvnice praktická a promyšlená (Paris: Éditions Ophrys, 1986); Český jazyk. Nová česká mluvnice praktická a promyšlená (Paris: Éditions Ophrys, 1995); 114 poznámek o polském jazyce pro studenty rusisty. Stručná mluvnice (Grenoble: Université Stendhal, 1981, tapuscrit); Neobvyklá mluvnice ruského jazyka. Syntax a komunikace (Grenoble: Université Stendhal, 1993) ${ }^{21}$. V sedmdesátých létech pracoval na Grammaire insolite de la langue russe. Syntaxe et communication. Od roku 1981 se začal zabývat studiem polštiny a redigoval Grammaire polonaise. Jeho třetím dílem v lingvistické oblasti je gramatika pod názvem La langue tchèque, jež vyšla v roce 1995.

Během své kariéry vytvářel velmi bohatou knihovnu věnovanou slovanské kultuře. V Bibliothèque Diderot v Lyonu lze studovat dokumenty o Alexandru Voronském (18841944), které věnoval lyonské knihovně v roce 2000. Archiválie shromažd’ují pramennou literaturu o Voronském, jeho dílo a čísla literárního časopisu, který založil roku 1921 pod názvem Krasnaja nov’. Claude Kastler je autorem knihy věnované tomuto ruskému literárnímu kritikovi a prozaikovi a nazval ji Un bolchévique fou de littérature (Bolševik

16 Tamtéž, s. 21-367.

17 CAPES - státní konkurz pro učitele druhého stupně.

18 COMTE, Philippe: In memoriam Claude Kastler. Revue Russe, 2011, č. 37, s. 6-8.

19 SLAVALP (Centre de recherche en études slaves) při Université Grenoble Alpes.

20 DESPRES, Isabelle: Claude Kastler (1936-2011). Revue des études slaves 82, 2011, č. 3, s. 579-581.

21 Ahoj, bohemisto, ahoj! Rozhovor s prof. Claudem Kastlerem. Rozhovor vedly L. Froulíková a T. Ibehejová. Krajiny češtiny. Časopis učitelů u krajanských komunit a lektorů českého jazyka a literatury na zahraničních vzdělávacích institucích, 2011, č. 3, s. 54. 
poblázněný literaturou). V roce 2015 věnovala vdova po Kastlerovi, Lioudmila Kastler, pedagožka a vědecká pracovnice na Université Grenoble Alpes, výše jmenované knihovně velkou část sbírky svého manžela. Kromě několika nových vydání Alexandra Voronského editovaných v Moskvě zásluhou jeho vnučky tento dar obsahoval především díla polská a česká. Polská část knihovny je reprezentována literaturou klasickou a současnou, dále díly historickými, geografickými a lingvistickými - výkladovým slovníkem Dictionnaire de la langue polonaise en 40 tomes, dvojjazyčnými slovníky (polonais-français, français-polonais, polonais-russe, polonais-allemands, polonais-anglais). Součást českého daru tvoří také literatura klasická a současná, díla vztahující se k české historii a odborná literatura z oblasti lingvistiky ${ }^{22}$.

Význačný francouzský slavista a lingvista Claude Kastler, pedagog, autor gramatik tří slovanských jazyků, díky své badatelské erudici a pedagogickému talentu přispěl zejména po roce 1989 k rozšíření znalosti češtiny a k propagaci české kultury ve francouzském prostředí, kde vychoval množství studentů, kteří našli profesní uplatnění ve vědě, v diplomatických službách, v překladatelství a cestovním ruchu. Jestliže si v příštím roce připomeneme desáté výročí jeho úmrtí, s jeho jménem zůstane spojen zejména praktický přínos pro výuku slovanských jazyků a literatur v této části románského světa.

\section{Literatura}

AUCOUTURIER, Michel: Ústav slovanských studii v Pařiži a Slovanský ústav v Praze. Slavia 68, 1999, č. 3-4, s. 393-394.

BERNARD, Antonia: Histoire de la slavistique. Le rôle des institutions. Paris: Institut d'études slaves, 2003.

BREUILLARD, Jean: Bref historique des études slaves en France. Revue du Centre Européen d' Etudes Slaves - Etudes slaves en France et en Europe. Numéro 1. Publié en ligne le 05 mars 2012. [citace 6. 2. 2019]. Dostupné: http://etudesslaves.edel.univ-poitiers.fr.

COMTE, Philippe: In memoriam Claude Kastler. Revue Russe, 2011, č. 37, s. 6-8. Dostupné z: https:// www.persee.fr/doc/russe_1161-0557_2011_num_37_1_2457.

DENIS, Arnošt: Ústav pro studium Slovanstva. Pařiž středisko slavistiky v cizině. Přel. Karel Havránek. Praha: nakladatel Jan Laichter, 1921.

DEPARIS, Véra - FOMENKO, Mireille: Les études slaves en France et en Europe. Paris: Institut d'études slaves, 2001.

DESPRES, Isabelle: Claude Kastler (1936-2011). Revue des études slaves (Paris) 82, 2011, č. 3, s. 579-581.

Dům zahraniční spolupráce. [online] [citace 16. 1. 2020]. Dostupné: https://www.dzs.cz/cz/program-podpory-ceskeho-kulturniho-dedictvi-v-zahranici/prehled-lektoratu-a-lektoru.

22 Fonds slaves de la Bibliothèque Diderot de Lyon, 2018. [online] [cit. 18. 11. 2019]. Dostupné: http://www. bibliotheque-diderot.fr/les-fonds-slaves-237260.kjsp?RH=bdl-0010\&RF=bdl-020302 a http://www.bibliotheque-diderot.fr/fonds-claude-kastler-1936-2011. 
Fonds slaves de la Bibliothèque Diderot de Lyon, 2018. [online] [cit. 18. 11. 2019]. Dostupné: http:/ / www.bibliotheque-diderot.fr/les-fonds-slaves-237260.kjsp?RH=bdl-0010\&RF=bdl-020302 a http://www.bibliotheque-diderot.fr/fonds-claude-kastler-1936-2011.

HAVRÁNEK, Bohumil: André Mazon, Grammaire de la langue tchèque. Naše řeč 7, 1923, č. 10, s. 298-305.

KARLÍK, Petr a kol.: Nový encyklopedický slovnik češtiny A-M. Praha: Nakladatelství Lidové noviny, 2016.

KASTLER, Claude: La langue tchèque. Nouvelle grammaire tchèque pratique et raisonnée. Paris: Ophrys, 1995.

Ahoj, bohemisto, ahoj! Rozhovor s prof. Claudem Kastlerem. Rozhovor vedly L. Froulíková a T. Ibehejová. Krajiny češtiny. Časopis učitelů u krajanských komunit a lektorů českého jazyka a literatury na zahraničních vzdělávacích institucích, 2011, č. 3, s. 52-54.

KUDĚLKA, Milan - ŠIMEČEK, Zdeněk - ŠŤASTNÝ, Vladislav - VEČERKA, Radoslav: Československá slavistika v letech 1918-1939. Praha: Academia, 1977.

VEČERKA, Radoslav: Jazyky v komparaci 1. Nástin české jazykovědné slavistiky v mezinárodním kontextu. Praha: Nakladatelství Lidové noviny, 2008.

ZELENKA, Miloš: Le rôle de la slavistique française dans l'essor institutionnel et l'orientation intellectuelle de la slavistique tchèque après 1918 (André Mazon et Matija Murko dans les années 1920). Revue des études slaves (Paris) 91, 2020, č. 1, s. 119-137.

\section{PhDr. Milena Nosková, Ph.D.}

Katedra slovanských jazyků a literatur

Pedagogická fakulta Jihočeské univerzity

Jeronýmova 10, 37115 České Budějovice, Česká republika

noskova@pf.jcu.cz

Toto dílo Ize užít v souladu s licenčními podmínkami Creative Commons BY-SA 4.0 International (https://creativecommons.org/licenses/by-sa/4.0/legalcode). Uvedené se nevztahuje na díla či prvky (např. obrazovou či fotografickou dokumentaci), které jsou v díle užity na základě smluvní licence nebo výjimky či omezení příslušných práv. 